\title{
Hemigrammus tocantinsi: a new species from the upper rio Tocantins basin, Central Brazil (Characiformes: Characidae)
}

\author{
Fernando R. Carvalho ${ }^{1}$, Vinicius A. Bertaco ${ }^{1}$ and Fernando C. Jerep ${ }^{2}$
}

Hemigrammus tocantinsi is described from the upper rio Tocantins basin, Chapada dos Veadeiros, Goiás State, Central Brazil. The new species differs from its congeners by the presence of 15-17 branched anal-fin rays, longitudinal stripe relatively narrow anteriorly and wider posteriorly, and one or two maxillary teeth. Sexual dimorphism of the new species is characterized by differences among the color in life, adipose-fin origin, body measurements, in addition to presence of bony hooks in the anal and pelvic fins of males.

Hemigrammus tocantinsi é descrito da bacia do alto rio Tocantins, Chapada dos Veadeiros, Goiás, Brasil Central. A espécie nova difere de seus congêneres por apresentar 15-17 raios ramificados da nadadeira anal, faixa longitudinal relativamente estreita anteriormente e ampla posteriormente e um ou dois dentes no maxilar. O dimorfismo sexual da nova espécie é caracterizado por diferenças no colorido em vida, origem da nadadeira adiposa, medidas corporais, além de ganchos nas nadadeiras anal e pélvica dos machos.

Key words: Ostariophysi, Chapada dos Veadeiros, Neotropical fish, Tocantins-Araguaia basin, Caudal-fin scales.

\section{Introduction}

Hemigrammus Gill is a group which houses small characids fishes, and includes 51 valid species widespread throughout South American river drainages from Orinoco to ParaguayParaná river basins (Lima et al., 2003; Bertaco \& Carvalho, 2005; Marinho et al., 2008; Lima \& Sousa, 2009). None of the diagnostic characters presently used to recognize Hemigrammus are unique to the genus, e. g., premaxillary teeth in two rows, five or more teeth on the inner premaxillary row, incomplete lateral line, and caudal fin scaled.

Eigenmann (1918) is still the most complete taxonomic review of Hemigrammus to date, and Géry (1977) made the last survey on the genus. Those authors recognized species groups based mainly on similarities of color pattern. No hypothesis of intrageneric relationships of Hemigrammus is available at the moment and the genus is non-monophyletic according to Mirande (2009), who assigned the genus to his Hemigrammus clade based on his weighed analysis, although not presenting any synapomorphy for the group.

The discovery of the new species was done during recent collections in rivers and streams from the upper rio Tocantins basin, in the Chapada dos Veadeiros region. The species herein described is treated as Hemigrammus since it better conforms to the Eigenmann's definition and represents the first species of the genus described to the rios Tocantins-Araguaia basin.

\section{Material and Methods}

Counts and measurements follow Fink \& Weitzman (1974) and Lima \& Moreira (2003), with the exclusion of the distance of snout to pectoral-fin origin, and the addition of the dorsalfin origin to adipose-fin origin, and head depth, which was measured at vertical through the posterior end of supraoccipital spine. Measurements were made with a caliper rule to the nearest $0.05 \mathrm{~mm}$ on the left side of the specimen whenever possible, and presented as percents of standard length (SL) or head length (HL). In the description, counts are followed by their frequency in parentheses, and an asterisk indicates the count of the holotype. In the list of paratypes and comparative material examined, the total number of specimens in the lot is followed by the number of those examined (in parentheses), cleared and stained (c\&s) individuals (if any), and SL of all specimens analyzed. Counts of vertebrae, supraneurals, gill-rakers of the first arch, branchiostegal rays, procurrent caudal-fin rays, and small

${ }^{1}$ Universidade Federal do Rio Grande do Sul, Instituto de Biociências, Departamento de Zoologia, Laboratório de Ictiologia. Av. Bento Gonçalves, 9500, 91501-970 Porto Alegre, RS, Brazil. frcarvalho2004@yahoo.com.br, vbertaco@gmail.com

${ }^{2}$ Setor de Ictiologia, Museu de Ciências e Tecnologia, Pontifícia Universidade Católica do Rio Grande do Sul. Av. Ipiranga 6681, Caixa Postal 1491, 90619-900 Porto Alegre, RS, Brazil. fjerep@yahoo.com.br 
dentary teeth were taken from five c\&s specimens prepared according to Taylor \& van Dyke (1985). Vertebral counts include the four vertebrae in the Weberian apparatus and the fused PU1+U1 of the caudal region as a single element. Pattern of circuli and radii was defined on scales sampled from the region between the lateral line and the insertion of pelvic-fin. Comparisons and data of species not available for examination were taken from the literature.

Institutional abbreviations follow Reis et al. (2003), with addition of Asociación Ictiológica, La Plata, Argentina (AI), Departamento de Zoologia, Universidade Federal do Rio Grande do Sul, Porto Alegre (UFRGS), and Laboratório de Ictiologia Sistemática, Universidade Federal do Tocantins, Porto Nacional (UNT).

\section{Hemigrammus tocantinsi, new species Figs. 1, 2, 3a, 4}

Holotype. MCP 44444, 28.2 mm SL, male, Brazil, Goiás, Cavalcante, rio das Pedras, Fazenda Córrego Fundo, 1344'34' $\mathrm{S} 47^{\circ} 26^{\prime} 33^{\prime \prime} \mathrm{W}, 8$ Sep 2009, F. R. Carvalho, V. A. Bertaco \& G. L. C. Frainer.

Paratypes. Brazil, Goiás State, municipality of Cavalcante, upper rio Tocantins basin. MCP 44508, 20, 22.8-26.8 mm SL; MNRJ 36005, 20, 23.8-29.9 mm SL; MZUSP 105072, 20, 23.4-26.7 mm SL; UFRGS 11300, 146 (36), 23.9-32.8 mm SL (5 c\&s, 25.3-29.1 mm SL); UFRGS 11836, 8 (ethyl alcohol anhydrous), 24.7-28.6 mm SL; UNT 9760, 15, 23.3-27.2 mm SL, collected with the holotype. UFRGS 9907, 10 (3), 25.9-27.6 mm SL, córrego Grotão or Maria Rita on GO 241 road, between Cavalcante and Minaçu, about $4 \mathrm{~km}$ north of Cavalcante, $13^{\circ} 45^{\prime} 18^{\prime}$ 'S $47^{\circ} 27^{\prime} 20^{\prime \prime} \mathrm{W}, 25$ May 2008, F. C. Jerep \& T. P. Carvalho. UFRGS 9910, 31 (5), 25.7-36.8 mm SL, stream about $3.5 \mathrm{~km}$ north of Cavalcante on GO 241 road, between

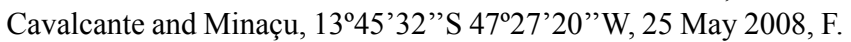
C. Jerep \& T. P. Carvalho. UFRGS 11292, 6 (2), 25.0-30.2 mm SL, same data as UFRGS 9910, 8 Sep 2009, F. R. Carvalho, V. A. Bertaco \& G. L. C. Frainer. UFRGS 11293, 2 (1), 31.3 mm SL, córrego LavaPés, about $300 \mathrm{~m}$ of road GO 241 road, $2 \mathrm{~km}$ Northeast of Cavalcante, 13\%47'17"S 47²6'27'W, 8 Sep 2009, F. R. Carvalho, V. A. Bertaco \& G. L. C. Frainer. UFRGS 11294, 61 (11), same data as UFRGS 9907, 6 Sep 2009, F. R. Carvalho, V. A. Bertaco \& G. L. C. Frainer.

Diagnosis. Hemigrammus tocantinsi differs from most congeners [except H. bellottii (Steindachner), H. bleheri Géry \& Mahnert, H. boesemani Géry, H. brevis Ellis, H. cylindricus Durbin, H. cupreus Durbin, $H$. erythrozonus Durbin, $H$. geisleri Zarske \& Géry, H. levis Durbin, H. mahnerti Uj \& Géry, H. microstomus Durbin, H. mimus Böhlke, H. orthus Durbin, H. rhodostomus Ahl, H. rodwayi Durbin, H. tridens Eigenmann, $H$. skolioplatus Bertaco \& Carvalho, and $H$. vorderwinkleri Géry] by the number of branched anal-fin rays, 15-17 (vs. less than 15 in H. analis Durbin, H. hyanuary Durbin, $H$. iota Durbin, and more than 17 on remaining species). From the species with the same range of branched anal-fin rays, Hemigrammus tocantinsi differs by the presence of 1-2 (mode 1) maxillary teeth (vs. 3-11 in H. bellottii, $H$. cylindricus, H. cupreus, H. mimus, and H. skolioplatus); longitudinal stripe posteriorly broad, larger than one scale depth or than pupil diameter (vs. thinner than one scale depth or pupil diameter or longitudinal stripe absent in $H$. bellottii, H. boesemani, H. brevis, H. erythrozonus, H. geisleri, H. levis, $H$. mahnerti, H. microstomus, $H$. orthus, $H$. rodwayi, $H$. tridens, and $H$. vorderwinkleri); caudal-fin lobes hyaline ( $v s$. presence of a conspicuous broad black marginal or submarginal band across the distal part of caudal-fin lobes in $H$. bleheri and H. rhodostomus). Furthermore, Hemigrammus tocantinsi can be distinguished from all congeners by the color pattern of live specimens (reddish or orange in male and yellowish pigmented in female).

Description. Morphometric data summarized in Table 1. Body compressed, moderately short, greatest body depth at vertical through dorsal-fin origin. Dorsal profile of head convex from tip of upper jaw to vertical through anterior nostril; slightly straight or convex from that point to tip of supraoccipital spine. Dorsal profile of body slightly convex from posterior tip of supraoccipital spine to base of last dorsal-fin ray, and straight to adipose-fin origin. Ventral profile of body convex from tip of lower jaw to pelvic-fin origin, straight or slightly convex from that point to anal-fin origin, and straight and posterodorsally slanted along anal-fin base. Dorsal and ventral profile of caudal peduncle approximately straight.

Eyes large, without distinct adipose eyelid. Jaw isognathous, mouth terminal. Maxilla extending posteriorly surpassing vertical through anterior margin of eye, aligned approximately at 45 degree angle relative to longitudinal axis of body. Nostrils close to each other, anterior opening smaller and circular, posterior one twice larger and oval. Median frontoparietal fontanel extending from mesethmoid to supraoccipital spine. Infraorbital series complete, with fourth infraorbital reduced dorsally (triangular shape) or absent sometimes, allowing contact between third and fifth infraorbitals. Infraorbital laterosensory canal close to inferior orbital margin, extending from posterior half of first infraorbital up to sixth orbital. Third infraorbital largest, double size of the others (in length and depth), contacting the preopercle laterosensory canal ventrally and posteriorly.

Premaxillary teeth in two rows: outer with $2(10), 3 *(39)$, or 4(10) tricuspid teeth (rarely pentacuspid); inner row with 4(13) or $5 *(46)$ pentacuspid teeth. Dentary with $4 *(54)$ or $5(5)$ large pentacuspid teeth, followed by a series of 4-6 small conical teeth (rarely tricuspid). Border of maxillary relatively straight. Maxilla with $1 *(55)$ or 2(4) tricuspid teeth along anteroventral margin (Fig. 2). Median cusp in all cuspidate teeth longer than remaining cusps; cusp tips slightly curved inwardly in dentary, premaxillary teeth cusps approximately straight.

Scales cycloid, with few radii (3-6), relatively short, at the margin of scale. Lateral line incomplete, slightly curved posteriorly, extending to vertical through distal tip of pectoral fin; perforated scales of lateral line 8(7), 9(7), 10(12), 11(12), $12 *(13), 13(4), 14(2)$, or 15(2); longitudinal scale series including pored scales 29(3), 30(14), 31(19), 32(8), 33*(6), or $34(7)$; $5 *(53)$ or $5 \frac{1}{2}(6)$ scale rows between dorsal-fin origin and lateral line; $3 \frac{1}{2}(25)$ or $4 *(34)$ scale rows between lateral 


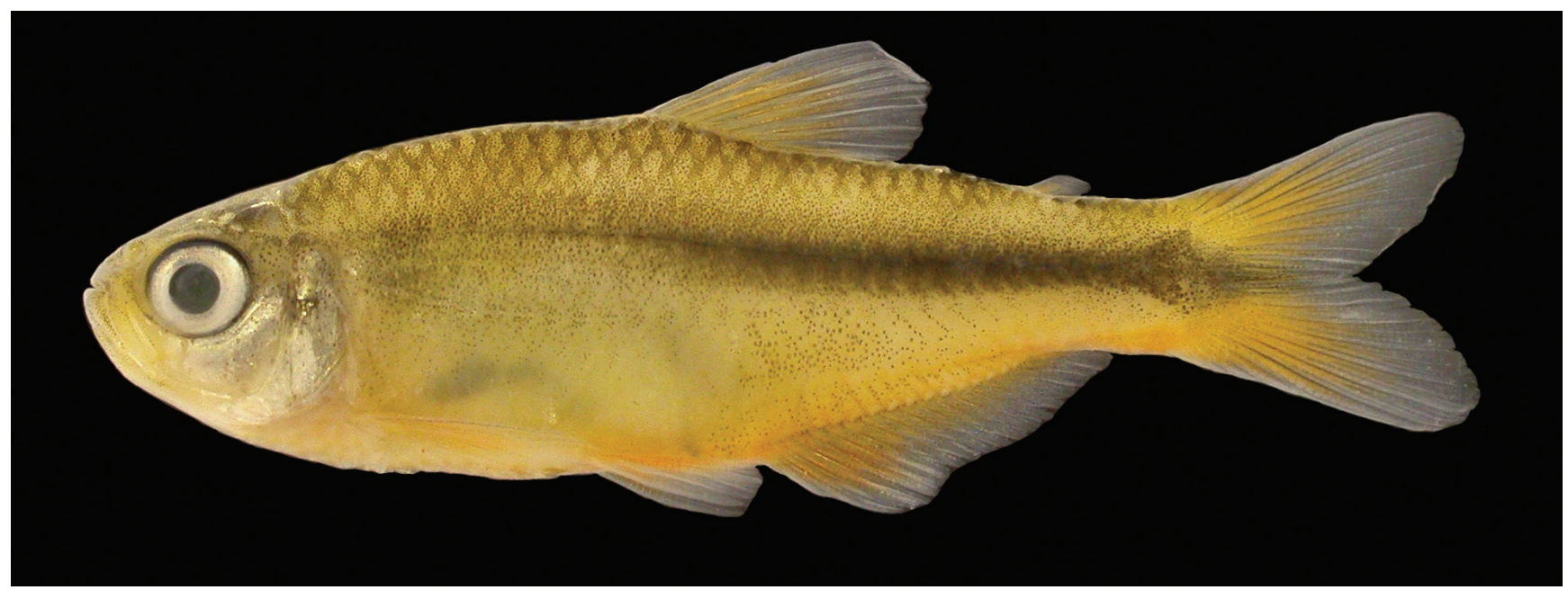

Fig. 1. Hemigrammus tocantinsi, holotype, male (few days after fixation), MCP 44444, $28.2 \mathrm{~mm}$ SL, rio das Pedras, Fazenda Córrego Fundo, municipality of Cavalcante, Goiás State, Brazil.

line and pelvic fin. Predorsal scales 10(4), 11*(49), or 12(6). Scale sheath along anal-fin base $5(2), 6(11), 7^{*}(22), 8(8)$, or $9(4)$ in a single row. Circumpeduncular scales $13(14)$ or $14 *(45)$. Axillary scale, longer than wide, relatively folded in half, and extending over 1-2 longitudinal scale series.

Dorsal-fin rays ii,8(4) or $9 *(55)$; first unbranched ray approximately half length of second one. Dorsal-fin origin at midbody, at vertical through anterior third of pelvic-fin base, base of last ray at vertical through base of second or third anal-fin branched ray. Tip of longest ray of adpressed dorsal fin at vertical through $8^{\text {th }}$ to $10^{\text {th }}$ anal-fin branched ray insertion. First dorsal-fin pterygiophore inserting behind neural spine of $5^{\text {th }}(1)$ or $6^{\text {th }}(4)$ vertebra. Adipose fin present. Pectoral fin i,9(14), 10*(36), or 11(9) rays. Pelvic fin i,6(2) or $7 *(57)$ rays. Pelvic-fin origin located anterior to vertical through dorsal-fin origin. Anal-fin rays iii, 15(14), 16(29), or $17 *(16)$. Caudal fin forked, lobes slightly rounded, similar in size, with i,8/8,i(1) or i, $9 / 8, i^{*}(58)$ rays. Caudal fin scaled, with scales along base of upper and one-third of lower caudal-fin lobe; scales gradually decreasing in size posteriorly (Fig. 3a). Dorsal procurrent caudal-fin rays 10(3), 11(2), and ventral procurrent caudal-fin rays 9(1) or 10(4).

Branchiostegal rays 4(5). First gill arch with 6(5) rakers on epibranchial, 1(5) between epibranchial and ceratobranchial, $10(5)$ in ceratobranchial, and 2(5) on hypobranchial. Precaudal vertebrae 16(5) and caudal vertebrae 17(4) or 18(1). Supraneurals $4(2)$ or 5(3), thin, not varying in width.

Color in alcohol. Overall body color varying from whitish to pale yellowish. Head dusk to dark brownish dorsally. Region from the posterior portion of second to fifth infraorbital and opercular apparatus silvery on specimens recently collected and yellowish on long time alcohol preservated ones. Small dark melanophores surrounding nare, lips, dorsal margin of maxillary bone, and anterior margin of orbit; larger melanophores scattered over infraorbitals three-six and opercular apparatus. Humeral region with concentration of melanophores occupying two scale rows above and one scale row bellow lateral line, resulting in faint humeral spot. Portion of spot above lateral line two scales wide and one scale wide bellow it. Dorsal and dorso-lateral portions of body with a reticulated pattern due to concentration of melanophores at the posterior margin of the scales. Lateral side of body with scattered melanophores, except at the abdominal region. Longitudinal stripe dark, one-scale wide, and extending from vertical through dorsal-fin origin to caudal-peduncle end, extending onto proximal one-third of middle caudal-fin rays. Lower lateral side of caudal region with few melanophores following the muscles epaxialis and hypaxialis superficial lines. All fins hyaline with scattered melanophores, sometimes bordering the margins of the rays.

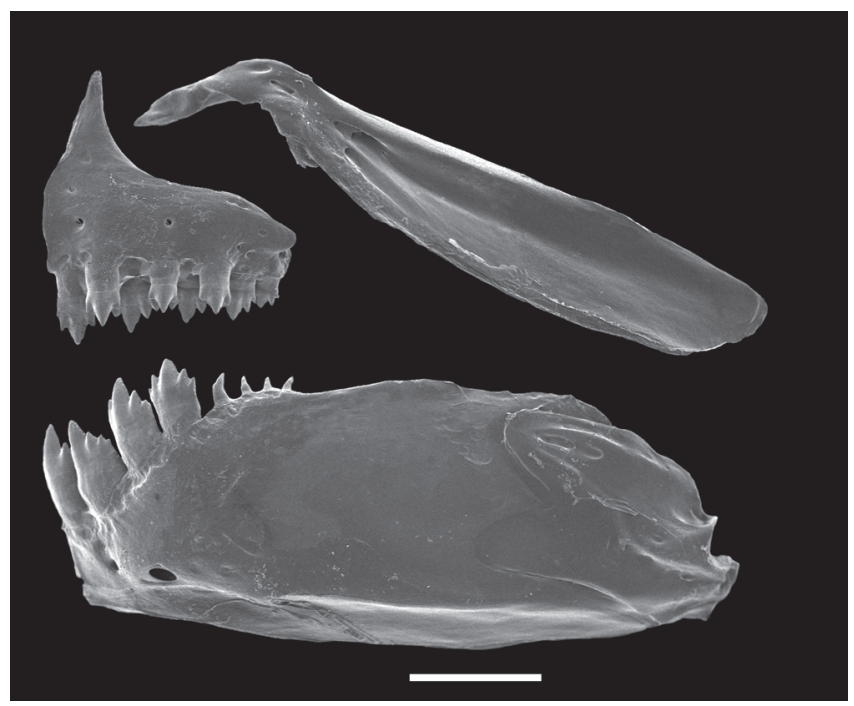

Fig. 2. Hemigrammus tocantinsi, paratype, female, UFRGS $11300,27.4 \mathrm{~mm}$ SL. Scanning electronic micrograph of lower and upper jaws, left side. Scale bar $=1 \mathrm{~mm}$. Maxillary tooth a little dislocated inwardly. 
Table 1. Morphometric data for holotype and 58 paratypes of Hemigrammus tocantinsi from upper rio Tocantins basin. $\mathrm{SD}=$ standard deviation; $\mathrm{m}=$ male $(\mathrm{n}=25$, including holotype); $\mathrm{f}=$ female $(\mathrm{n}=34)$.

\begin{tabular}{|c|c|c|c|c|}
\hline & Holotype & Paratypes & Mean & $\mathrm{SD}$ \\
\hline Standard length (mm) & 28.2 & $23.9-36.8$ & 26.9 & - \\
\hline \multicolumn{5}{|c|}{ Percents of standard length } \\
\hline Body depth & 32.5 & $29.7-36.6$ & 32.9 & 1.4 \\
\hline Head length & 25.3 & $23.0-27.6$ & 26.0 & 0.8 \\
\hline Head depth & 27.2 & $25.6-32.3$ & 27.5 & 1.0 \\
\hline Predorsal length & 52.9 & $51.3-55.7$ & 53.9 & 0.9 \\
\hline Prepelvic length & 47.7 & $46.5-51.8$ & 48.8 & 1.1 \\
\hline Pelvic fin to anal distance (m) & 16.4 & $14.5-17.6$ & 16.1 & 0.7 \\
\hline Pelvic fin to anal distance (f) & - & $15.7-20.2$ & 18.1 & 1.0 \\
\hline Caudal peduncle depth & 13.9 & $12.2-15.3$ & 13.8 & 0.7 \\
\hline Dorsal-fin base length & 13.5 & $11.3-14.9$ & 13.0 & 0.8 \\
\hline Anal-fin base length (m) & 26.7 & $23.4-28.8$ & 26.5 & 1.1 \\
\hline Anal-fin base length (f) & - & $20.1-27.5$ & 23.3 & 1.8 \\
\hline Pectoral-fin length (m) & 22.2 & $22.2-25.5$ & 23.7 & 0.8 \\
\hline Pectoral-fin length (f) & - & $19.0-23.9$ & 21.8 & 1.1 \\
\hline Pelvic-fin length (m) & 16.9 & $16.5-18.4$ & 17.4 & 0.5 \\
\hline Pelvic-fin length (f) & - & $13.4-17.4$ & 14.8 & 1.2 \\
\hline Dorsal-fin length (m) & 26.9 & $26.1-31.0$ & 28.2 & 1.2 \\
\hline Dorsal-fin length (f) & - & $23.2-29.2$ & 26.1 & 1.5 \\
\hline Anal-fin length & 17.1 & $14.6-21.8$ & 17.5 & 1.5 \\
\hline Caudal peduncle length & 17.0 & $15.5-19.0$ & 17.4 & 0.8 \\
\hline Dorsal fin to adipose fin distance & 36.2 & $33.3-37.5$ & 35.2 & 0.9 \\
\hline Eye to dorsal-fin origin & 39.7 & $37.9-42.1$ & 40.1 & 0.9 \\
\hline Dorsal origin to caudal origin & 51.6 & $49.0-55.0$ & 51.5 & 1.2 \\
\hline \multicolumn{5}{|c|}{ Percents of head length } \\
\hline Interorbital width & 31.0 & $29.4-35.1$ & 32.1 & 1.2 \\
\hline Snout length & 22.9 & $20.4-25.9$ & 22.8 & 1.0 \\
\hline Orbital diameter & 40.7 & $38.6-46.2$ & 42.8 & 1.7 \\
\hline Upper jaw length & 43.3 & $36.8-43.5$ & 40.9 & 1.5 \\
\hline
\end{tabular}

Color in life. Overall body and head color pattern reddish in males and yellowish in females. Pattern of melanophores distribution on head, body and fins similar to that described for specimens in alcohol. Proximal two thirds of dorsal, pectoral, pelvic, anal and caudal-fin rays red-orange in males and yellowish in females, except middle caudal-fin rays. Proximal portion of adipose fin and ventral surface of body from the end of pelvic-fin insertion to lower caudal-fin rays origin orange to reddish in males and yellowish in females (Fig. 4) (see also Sexual dimorphism).

Sexual dimorphism. Bony hooks on pelvic and anal-fin ray were observed only in males larger than $23.9 \mathrm{~mm}$ SL. Pelvic fin of males bearing small bony hooks along ventromedial border of first to fifth branched rays; one hook per ray segment. Anal fin with small bony hooks situated on distal portion of anal-fin rays, from the last unbranched anal-fin ray to first to eighth branched rays; one hook per ray segment. Males and females also differ in proportions of the pectoral and pelvic fins (Fig. 5), dorsal- and anal-fin base length, and pelvic fin to anal fin distance (Table 1), and in the anal-fin distal border shape, which is approximately straight on males and slightly concave in the anterior portion in females. Adipose fin located immediately after vertical through last branched anal-fin ray insertions in females and at vertical through last three or four anal-fin ray insertions in males. Tip of longest ray reaching anal-fin origin in males but not in females. Live specimens, or just after fixation,
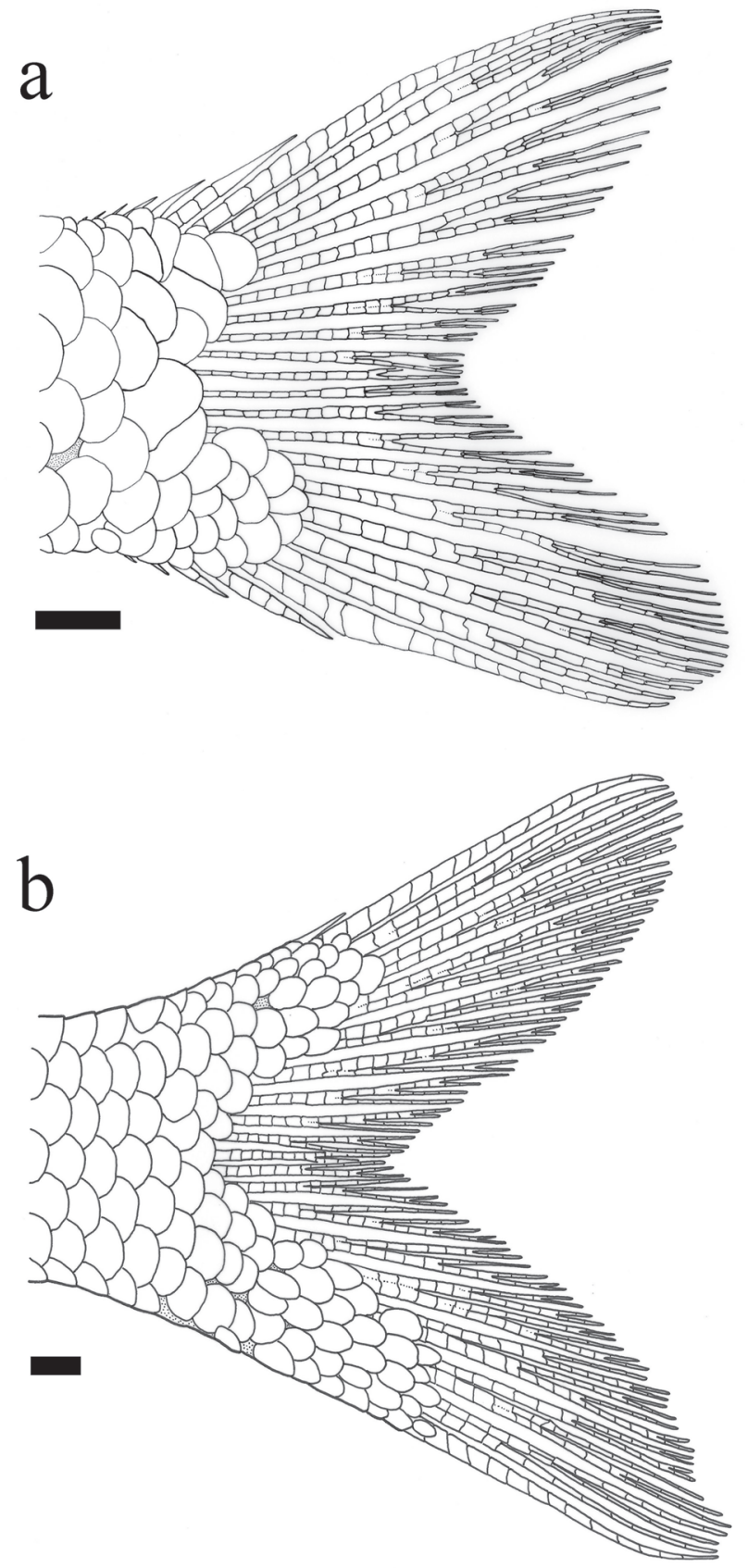

Fig. 3. Caudal squamation: (a) Hemigrammus tocantinsi, paratype, UFRGS 9907, $27.3 \mathrm{~mm} \mathrm{SL}$ and (b) Hemigrammus marginatus, MCP 43324, $32.4 \mathrm{~mm}$ SL. Scale bars $=1 \mathrm{~mm}$.

possess body and fins red to orange on males and yellowish in females (Fig. 4). Gill glands (Burns \& Weitzman, 1996) were not found on first gill arch on both males and females.

Distribution. Hemigrammus tocantinsi occurs in the tributaries of the rio das Almas, rio Paranã drainage, upper rio Tocantins basin, Goiás State, Brazil (Fig. 6).

Etymology. The specific name tocantinsi is a reference to the rio Tocantins basin, where the new species inhabit. A noun in apposition. 

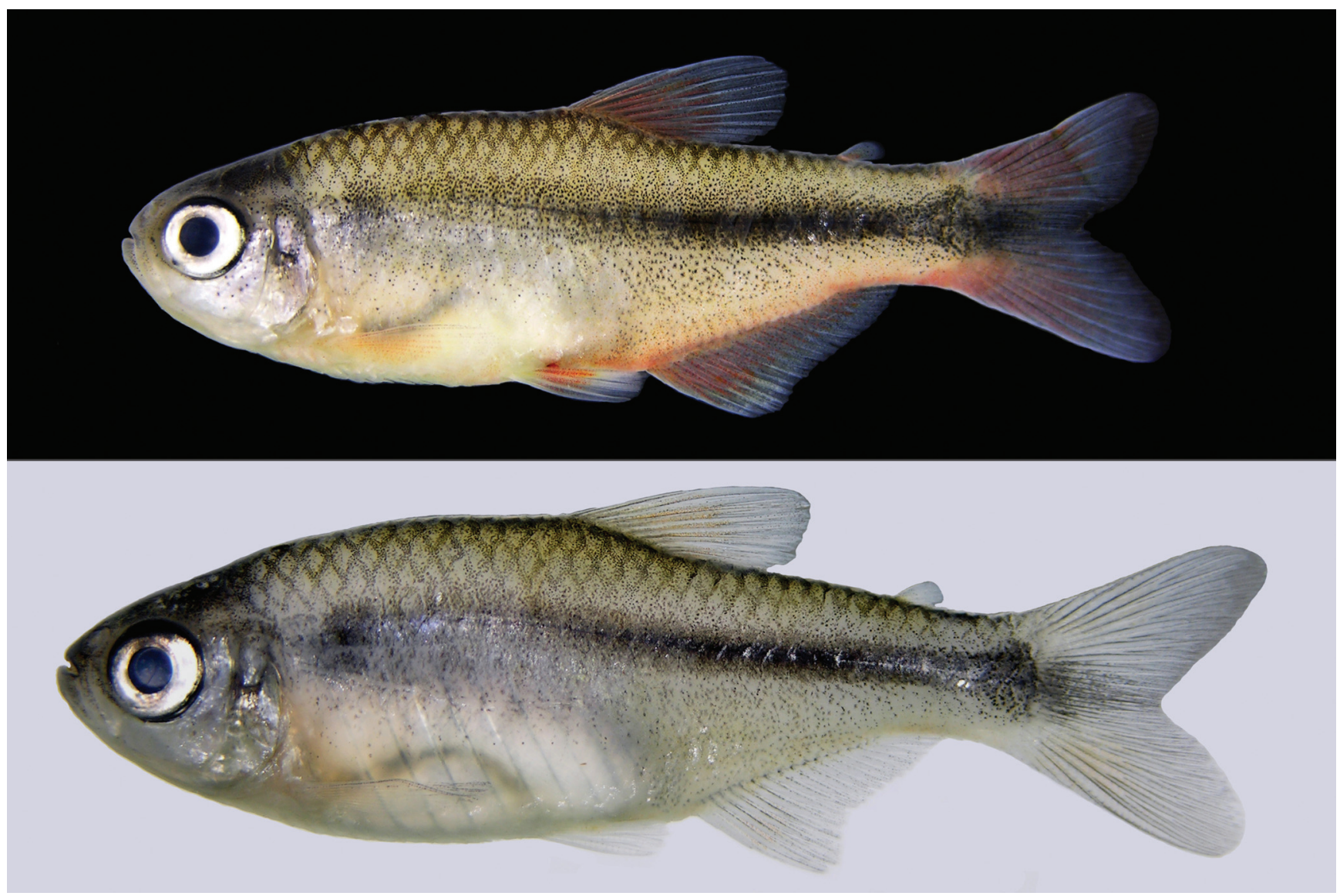

Fig. 4. Hemigrammus tocantinsi, paratypes, UFRGS 11300, male above, $27.3 \mathrm{~mm}$ SL and female below, $29.5 \mathrm{~mm}$ SL. Images of specimens just after fixation.

Ecological notes. The new species lives in streams, occuring in semi-lentic and lotic shallow areas (up to $1 \mathrm{~m}$ deep) with riparian vegetation composed by trees and shrubs (Fig. 7). The new species was collected syntopically with Aspidoras albater, Astyanax sp., Characidium stigmosum, Corumbataia veadeiros, and Trichomycterus sp. Stomach contents of five specimens (UFRGS 11300, 25.1-27.1 mm SL) were mainly composed by Diptera (pupae) and allochthonous insects, but it was also found authochthonous insects and digested vegetal matter in a lesser amount.

Spermatozoa. Hemigrammus tocantinsi has a typical aquasperm with spherical to slightly ovoid nucleus (UFRGS $11300,25.1 \mathrm{~mm} \mathrm{SL})$, suggesting that the species is noninseminating (Burns \& Weitzman, 2005) (Fig. 8).

\section{Discussion}

The new species, Hemigrammus tocantinsi, is herein assigned to Hemigrammus according to the definition of the genus given by Eigenmann $(1917,1918)$ and Géry $(1977)$, which is still in use (Bertaco \& Carvalho, 2005; Zarske et al., 2006; Benine \& Lopes, 2007; Zarske \& Géry, 2007; Marinho et al., 2008; Lima et al., 2009) due to the absence of a cladistic definition of the genus. In a recent phylogeny of Characidae including
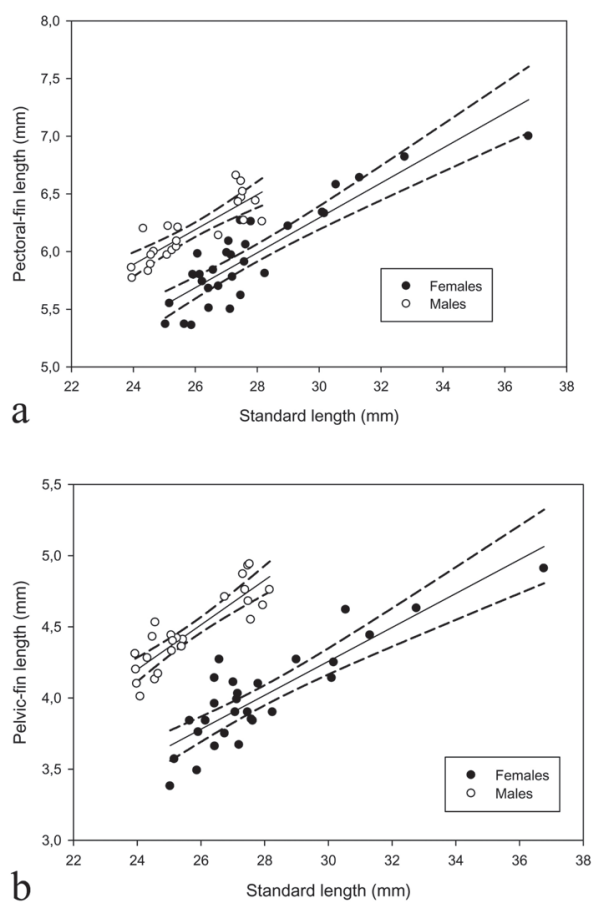

Fig. 5. Hemigrammus tocantinsi: (a) pectoral-fin length and (b) pelvic-fin length as function of standard length in males and females. 


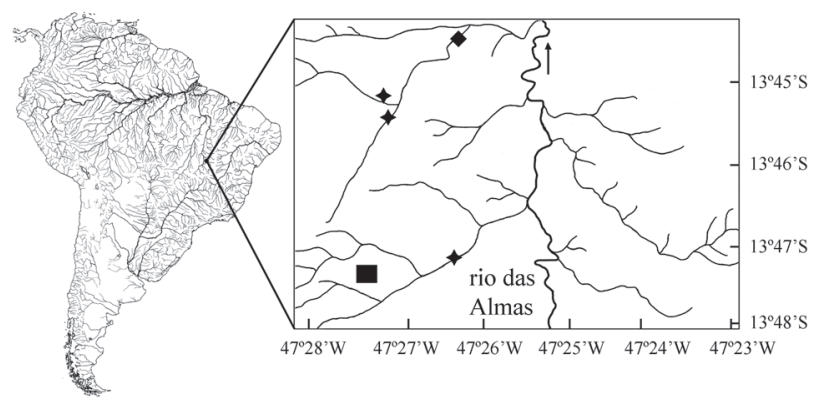

Fig. 6. Geographic distribution of Hemigrammus tocantinsi in rio das Almas drainage, upper rio Tocantins basin, Brazil. Rectangle $=$ municipality of Cavalcante, $\mathrm{GO}$; stars $=$ localities of occurrence of $H$. tocantinsi; lozenge = type-locality. Arrow shows the direction of rio das Almas flow.

most of its representative genera, Mirande (2009) found a monophyletic group in his weighed parsimony analysis named as Hemigrammus clade, which included Hemigrammus as well as the previously considered incertae sedis genera Bario, Deuterodon, Hasemania, Hyphessobrycon, Moenkhausia, Myxiops, Paracheirodon, Petitella, Pristella, Probolodus, and Thayeria. In that analysis, the four Hemigrammus species $(H$. erythrozonus, $H$. cf. rhodostomus, H. ulreyi, and H. unilineatus) did not constituted a monophyletic lineage. Although Mirande (2009) did not present the synapomorphies for the Hemigrammus clade, his results corroborated the hypothesis that Hemigrammus is a non-monophyletic entity, as previously suggested by various authors (e.g. Lucena, 2003; Malabarba \& Weitzman, 2003; Marinho et al., 2008; Lima et al., 2009). Therefore, Hemigrammus is still recognized by a combination of non unique characters which are partially shared with other incertae sedis Characidae genera, such as Astyanax, Hyphessobrycon, and Moenkhausia, dimming the true boundary of genus.

The classical definition of Hemigrammus differs from Hyphessobrycon only by the presence of scales over the caudal-fin lobes. Descriptions of Hemigrammus species

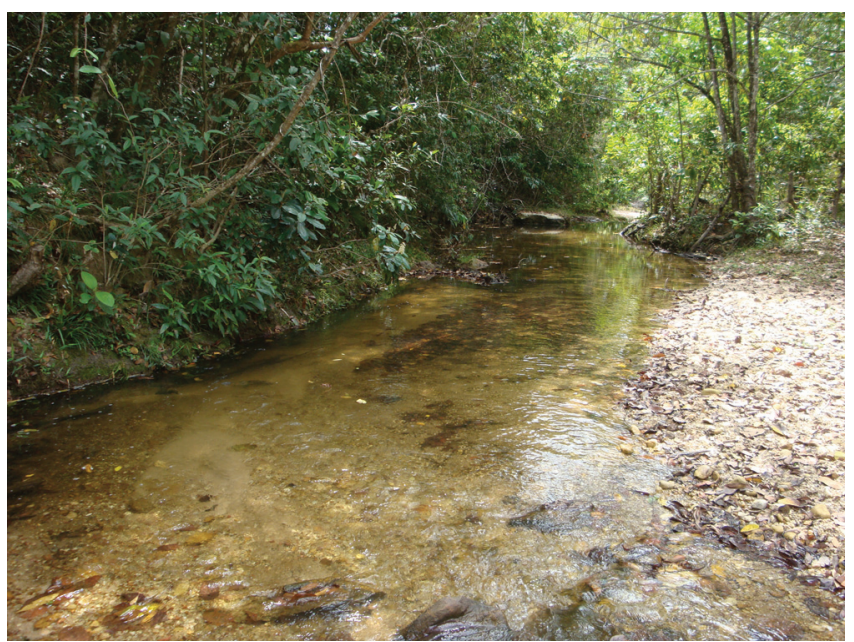

Fig. 7. Type locality of Hemigrammus tocantinsi, Brazil, Goiás, Cavalcante, rio das Pedras, Fazenda Córrego Fundo. usually only remark the presence of the caudal-fin scales, rarely describing their shape, size or distribution pattern. In fact, dealing with this character is not an easy task. The scales covering the caudal-fin lobes are feeble and easily lost by friction even on recent collected material. Finding an intact caudal fin with its scales at the original position is unusual on specimens from collections, and very unlikely on old type material. This lack of data obscures how much information the caudal-fin squamation could bring to elucidate the evolutionary history of the Hemigrammus and other Characidae species. Hemigrammus tocantinsi has scales covering one-third of the lower caudal lobe (Fig. 3a). The scales cover a smaller extension of the caudal-fin lobe than found in other Hemigrammus species, like H. marginatus (Fig. 3b), but larger than found on Hyphessobrycon species, what could raise some doubt about its generic position. A similar condition was also described by Böhlke (1955) for Hemigrammus mimus, considered by him as an "intermediate [state] between what Dr. Eigenmann referred to as "caudal scaled' and 'caudal naked except at its base' ". Problems concerning variation on caudal-fin scale patterns were also observed in Bryconamericus and Knodus, where Knodus meridae, the type species of the genus, presents similar caudal-fin scale arrangement to Bryconamericus iheringii (see figs. 12 to 14 in Weitzman et al., 2005). As asserted by the former authors, probably the caudal-fin squamation has a complex evolutionary history, and the comparison of caudalfin scale patterns among species of Hemigrammus and Hyphessobrycon for phylogenetic purposes needs detailed ontogenetic study, as well as in Bryconamericus and Knodus. The new species herein described is designated to Hemigrammus at the moment and further discussion about its generic position depends on phylogenetic studies including the species. Detailed studies of squamation on caudal fin will possibly benefit the results.

When compared to Hyphessobrycon species, Hemigrammus tocantinsi would be assigned to "group d" of Géry (1977), which includes species with both humeral and caudal spots, and a longitudinal band or line along the body (such as H.tropis). The species from this group were updated by Carvalho et al. (2008), now with addition of H. hamatus

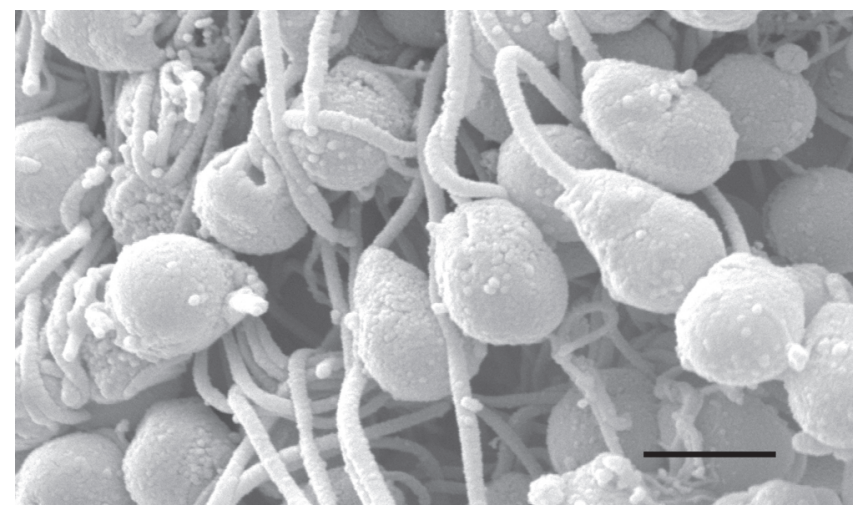

Fig. 8. Hemigrammus tocantinsi, paratype, spermatozeugmata, UFRGS 11300, $25.1 \mathrm{~mm}$ SL. Scale bar $=2 \mu \mathrm{m}$. 
Bertaco \& Malabarba, H. ocasoensis García-Alzate \& RománValencia, and $H$. vinaceus Bertaco, Malabarba \& Dergam. Hemigrammus tocantinsi differs from all species of that group by the number of branched anal-fin rays 15-17 ( $v s$. more than 17 in $H$. anisitsi, $H$. auca, $H$. boulengeri, $H$. hildae, $H$. inconstans, $H$. luetkenii, $H$. maculicauda, H. melazonatus, H. ocasioensis, H. proteus, H.tenuis, and H. togoi); by having orbital diameter $38.6-46.2 \%$ HL (vs. $31.9-33.3 \%$ in $H$. duragenys; $29.1-33.7 \%$ in $H$. hamatus; $24.4-37.5 \%$ in $H$. langeanii; $35.2-37.9 \%$ in $H$. santae; $24.2-31.4 \%$ in $H$. vinaceus), by having 0-2 maxillary teeth (vs. 5-7 in H. eos; 4-6 in H. frankei; 4-5 in H. robustulus; 3-5 in H. rutiliflavidus; 8 in $H$. tropis), and by having pentacuspids teeth of inner premaxillary row (vs. hepta- or more cusps in $H$. isiri).

Hasemania Ellis is a similar genus to Hemigrammus and Hyphessobrycon, but lacking the adipose fin. Hemigrammus tocantinsi has general body shape to Hasemania hanseni (Fowler) (from upper rio Paraná basin), but differs that from by having 1-2 maxillary teeth ( $v s$. zero), adipose fin always present ( $v s$. absent), humeral spot present ( $v s$. absent), and mouth terminal ( $v s$. superior).

Hemigrammus tocantinsi possesses a chromatic sexual dimorphism, a character not commonly described in the literature among species of the genus. Among Characidae genera, only Hyphessobrycon (H. bifasciatus Ellis, H. negodagua Lima \& Gerhard, and H. rutiliflavidus Carvalho, Langeani, Miyazama \& Troy), and Hemigrammus rodwayi present a similar sort of sexual dimorphism documented. However, the new taxon differs from Hyphessobrycon species by having the caudal fin scaled.

The upper rio Tocantins ichthyofauna, including the Chapada dos Veadeiros region, is markedly evidenced by its high degree of endemism, as listed in recent studies ( $c f$. Bertaco \& Carvalho, 2010; Bertaco et al., 2010). The rugged landscape of the region provides several waterfalls and numerous headwater streams with barriers to dispersion that, allied to low the capacity of displacement of small fish species, allow the occurrence of vicariant events that lead to high degree of speciation by allopatry (Castro, 1999). Thus, we recommend special scientific attention to areas that retain species with restricted distribution, as pointed out by Böhlke et al. (1978) thirty and two years ago. The Chapada dos Veadeiros region is one of such areas.

Comparative material examined. In addition to the comparative material listed in Bertaco \& Carvalho (2005), Bertaco \& Carvalho (2010), Bertaco et al. (2007), Carvalho et al. (2008), Marinho et al . (2008) the following specimens were analyzed: Hemigrammus aereus, USNM 179759, paratype, $21.4 \mathrm{~mm}$ SL, French Guiana, Nancibo creek Conte basin. Hemigrammus analis, USNM 66192, paratype, $19.2 \mathrm{~mm}$ SL, Guyana, Gluck Island, Britsh Guiana (the specimen in the jar is not a $H$. analis, but a $H$. rodwayi), USNM 66193, paratypes, 2, 21.4-21.7 mm SL, Guyana, Rockstone, British Guiana. Hemigrammus armstrongi, USNM 163868, holotype, 19.3 mm SL, Guyana, British Guiana, Georgetown. Hemigrammus arua, MZUSP 100370, paratypes, 29(1), 20.8 mm SL, Brazil, Pará, Juriti, igarapé São Francisco do Alto Aruanã. Hemigrammus barrigonae, USNM 272280, 200(19), 22.5-27.2 mm SL, Venezuela, Amazonas, Ature, caño about $15 \mathrm{~km}$ South of El Burro on road from Puerto Ayacucho to El Burro. Hemigrammus bleheri, MZUSP 37369, holotype, $35.8 \mathrm{~mm} \mathrm{SL}$, Brazil, middle rio Negro basin, (probably near rio Jufaris). Hemigrammus compressus, FMNH 4641, holotype, $30.7 \mathrm{~mm}$ SL, Mexico, Oaxaca, río Papaloapam basin at El Hule. Hemigrammus cylindricus, USNM 66191, paratype, 39.5 mm SL, Guyana, Crabs falls, British Guiana. Hemigrammus erythrozonus, USNM 66187, paratypes, 2, 18.4-19.5 mm SL, Guyana, Erukin (Bristish Guiana). Hemigrammus guyanensis, USNM 179756, paratypes, 9, 18.0-21.9 mm SL, French Guiana, Maroni, creek toward Ga Kaba. Hemigrammus inconstans, USNM 34591, holotype, 41.9 mm SL, Brazil, Pará. Hemigrammus levis, USNM 120266, syntypes, 6, 31.4-40.5 mm SL, Brazil, lago do Máximo. Hemigrammus marginatus, MCP 43324, mm SL, 483(6), 21.2-32.4 mm SL, Brazil, Rio Grande do Norte, Parnamirim, rio Pitimbu. Hemigrammus melanochrous, ANSP 39228, holotype, 24.3 mm SL, ANSP 39229, paratype, 22.0 mm SL, Brazil, Rondônia, Porto Velho, tributary of rio Madeira, near Porto Velho. Hemigrammus micropterus boesemani, USNM 179758, paratype, $26.6 \mathrm{~mm}$ SL, French Guiana, creek near Sinnamary. Hemigrammus microstomus, USNM 120267, paratypes, 3, 22.6-24.2 mm SL, Brazil, Pará, Santarém. Hemigrammus mimus, CAS 147759, holotype, $27.8 \mathrm{~mm}$ SL, Brazil, Amazonas, rio Negro, below São Gabriel da Cachoeira. Hemigrammus minutus, USNM 78628, paratypes, 29(20), 22.9-33.0 mm SL, Panama, Aqua Clara, Canal Zone. Hemigrammus newboldi, INHS 28030, 40(10), 29.6-34.0 mm SL, Venezuela, caño Caicara, río Apure Dr. Hemigrammus ocellifer, MZUSP 7272, 239(7), 25.8-31.8 mm SL, Brazil, Amazonas, Maués, igarapé of rio Maraú. Hemigrammus orthus, USNM 66190, paratype, $13.6 \mathrm{~mm} \mathrm{SL}$, British Guiana, Gluck Island. Hemigrammus pulcher haraldi, USNM 196672, holotype, 27.2 mm SL, Brazil, upper Solimões, in land lake between Paraná-Pará and ParanáComatia. Hemigrammus proneki, USNM 198648, holotype, 29.2 mm SL, Brazil, Amazonas, upper rio Negro, near Tapurucuara. Hemigrammus rhodostomus, USNM 273367, paralectotypes, 2, 23.7-28.3 mm SL, Brazil, Pará. Hemigrammus rodwayi, USNM 66188, paratypes, 5, 30.7-35.5 mm SL, Guyana, Georgetown Trenches, Botanic garden, Aruka and Barima rivers. Hemigrammus silimoni, MZUSP 93559, holotype, $29.0 \mathrm{~mm} \mathrm{SL}$, Brazil, Mato Grosso, Sapezal, rio Juruena, downstream PCH Telegráfica. Hemigrammus taphorni, MCNG 55841, holotype, $34.4 \mathrm{~mm} \mathrm{SL}$ and MCNG 55842, paratypes, 8, 26.8-31.2 mm SL, Venezuela, Bolivar, rio Caura, caño Mayor, around Salto Para. Hemigrammus tridens, CAS 58609, holotype, 17.7 mm SL, Paraguay, arroyo Pypucu, about $120 \mathrm{~km}$ from rio Paraguay. Hemigrammus unilineatus cayennensis, USNM 179757, paratypes, 2, 26.7-30.6 mm SL, French Guiana, creek from the water of Cayenne I. Hemigrammus ulreyi, MZUSP 19100, 11(2), 28.10-30.5 mm SL, Brazil, Mato Grosso, Descalvados, rio Paraguay. Hemigrammus vorderwinkleri, USNM 198643, holotype, $32.1 \mathrm{~mm}$ SL, Brazil, Amazonas, upper rio Negro, near Tapurucuara. Hemigrammus yinyang, MZUSP 99300, holotype, 29.2 mm SL, Brazil, Amazonas, igarapé Castanha, near sítio São Pedro.

\section{Acknowledgements}

We are indebted to Guilherme Frainer (UFRGS) by his help in the specimens collecting; Andréia Turcati (UFRGS) by helping with the analysis of stomach contents; Tiago Carvalho (University of Louisiana at Lafayette) for identification of Corumbataia veadeiros; Manoela Marinho (MZUSP) by data of Hemigrammus hyanuary. We are thankful to Paulo Lucinda (UNT) by helping on the name composition of the new species. For museum and technical support and/or loan of material we thanks Osvaldo 
Oyakawa, Flávio Lima (MZUSP), Carlos Lucena (MCP), Ricardo Benine (LBP), Amalia Miquelarena (UNLP), Mary A. Rogers, Kevin Swagel (FMNH), Richard Vari, Sandra Raredon, Jerry Finan, JeffClayton, Jeff Willians (NMNH), John Lundberg, Mark SabajPérez (ANSP), David Catania, Jon Fong (CAS), and Mike Retzer (INHS). We thank to CME (UFRGS) for the SEM preparations. This manuscript greatly benefited from the suggestions of two anonymous referees. FRC and FCJ are supported by a doctoral fellowship from CNPq (Procs. 141028/2007-6 and 201513/2009-9) and CAPES respectively. VAB is financed by a postdoctoral fellowship from CNPq (Proc. 150042/2009-4). Field work support was in part provided by CNPq (Proc. 479412/2008-1). Collecting permits were provided by Instituto Brasileiro do Meio Ambiente e dos Recursos Naturais Renováveis - IBAMA (\# 1507-1).

\section{Literature Cited}

Benine, R. C. \& G. A. M. Lopes. 2007. A new species of Hemigrammus Gill, 1858 (Characiformes: Characidae) from río Caura, Venezuela. Zootaxa, 1610: 53-59.

Bertaco, V. A. \& F. R. Carvalho. 2010. New species of Hasemania (Ostariophysi: Characiformes: Characidae) from Central Brazil, with comments on the endemism of upper rio Tocantins basin, Goiás State. Neotropical Ichthyology, 8(1): 27-32.

Bertaco, V.A. \& T. P. Carvalho. 2005. New characid fish, Hemigrammus skolioplatus (Characiformes: Characidae) from upper rio Tapajós drainage, Central Brazil. Comunicações do Museu de Ciências e Tecnologia da PUCRS, Série Zoologia, 18(2): 141-150.

Bertaco, V. A., F. R. Carvalho \& F. C. Jerep. 2010. Astyanax goyanensis (Miranda-Ribeiro, 1944), new combination and Astyanax courensis, new species (Ostariophysi: Characiformes): two Characidae from the upper rio Tocantins basin, Central Brazil. Neotropical Ichthyology, 8(2): 265-275.

Bertaco, V. A., L. R. Malabarba \& J. A. Dergam. 2007. New Hyphessobrycon from the upper rio Pardo drainage in eastern Brazil (Teleostei: Characiformes: Characidae). Neotropical Ichthyology, 5(3): 245-249.

Böhlke, J. E. 1955. Studies on fishes of the family Characidae.-No. 8. The description of a new Hemigrammus from the rio Negro of Brazil. Transactions of the Kansas Academy of Science, 58(1): 229-236.

Böhlke, J. E., S. H. Weitzman \& N. A. Menezes. 1978. Estado atual da sistemática dos peixes de água doce da América do Sul. Acta Amazonica, 8(4): 657-677.

Burns, J. R. \& S. H. Weitzman. 1996. Novel gill-derived gland in the male swordtail characin, Corynopoma riisei (Teleostei: Characidae: Glandulocaudinae). Copeia, 1996(3): 627-633.

Burns, J. R. \& S. H. Weitzman. 2005. Insemination in ostariophysan fishes, Pp. 107-134. In: Uribe, M. C. \& H. J. Grier (Eds.).Viviparous Fishes. New Life Publications, Homestead, Florida, 609p.

Castro, R. M. C. 1999. Evolução da ictiofauna de riachos sul-americanos: padrões gerais e possíveis processos causais. Pp. 139155. In: Caramaschi, E. P., R. Mazzoni \& P. R. Peres-Neto (Eds.). Ecologia de peixes de riachos: estado atual e perspectivas. Série Oecologia Brasiliensis, PPGE-UFRJ, Rio de Janeiro, VI, 260p.

Carvalho, F. R., F. Langeani, C. S. Miyazawa \& W. P. Troy. 2008. Hyphessobrycon rutiliflavidus n. sp., a new characid fish from the upper rio Paraguai, State of Mato Grosso, Brazil (Characiformes: Characidae). Zootaxa, 1674: 39-49.
Eigenmann, C. H. 1917. The American Characidae [Part 1]. Memoirs of the Museum of Comparative Zoology 43(1): 1-102.

Eigenmann, C. H. 1918. The American Characidae [Part 2]. Memoirs of the Museum of Comparative Zoology 43(2): 103-208.

Fink, W. L. \& S. H. Weitzman. 1974. The so-called cheirodontin fishes of Central America with descriptions of two new species (Pisces: Characidae). Smithsonian Contributions to Zoology, 172: 1-46.

Géry, J. 1977. Characoids of the World. T. F. H. Publications, Neptune City, NJ, 672p.

Lima, F. C. T., L. R. Malabarba, P. A. Buckup, J. F. Pezzi da Silva, R. P. Vari, A. Harold, R. Benine, O. T. Oyakawa, C. S. Pavanelli, N. A. Menezes, C. A. S. Lucena, M. C. S. L. Malabarba, Z. M. S. Lucena, R. E. Reis, F. Langeani, L. Casatti, V. A. Bertaco, C. Moreira \& P. H. F. Lucinda. 2003. Genera incertae sedis in Characidae. Pp. 106-169. In: Reis, R. E., S. O. Kullander \& C. J. Ferraris (Eds.). Check List of the Freshwater Fishes of South and Central America. Porto Alegre, Edipucrs, 729p.

Lima, F. C. T. \& C. R. Moreira. 2003. Three new species of Hyphessobrycon (Characiformes: Characidae) from the upper rio Araguaia basin in Brazil. Neotropical Ichthyology, 1(1): 21-33.

Lima, F. C. T. \& L. M. Sousa. 2009. A new species of Hemigrammus from the upper rio Negro basin, Brazil, with comments on the presence and arrangement of anal-fin hooks in Hemigrammus and related genera (Ostariophysi: Characiformes: Characidae). Aqua, International Journal of Ichthyology, 15(3): 153-168.

Lima, F. C. T., W. B. Wosiacki \& C. S. Ramos. 2009. Hemigrammus arua, a new species of characid (Characiformes: Characidae) from the lower Amazon, Brazil. Neotropical Ichthyology, 7(2): 153-160.

Lucena, C. A. S. 2003. New characid fish, Hyphessobrycon scutulatus, from the rio Teles Pires drainage, upper rio Tapajós system (Ostariophysi: Characiformes: Characidae). Neotropical Ichthyology, 1(2): 93-96.

Malabarba, L. R. \& S. H. Weitzman. 2003. Description of a new genus with six new species from southern Brazil, Uruguay and Argentina, with a discussion of a putative characid clade (Teleostei: Characiformes: Characidae). Comunicações do Museu de Ciências e Tecnologia da PUCRS, Série Zoologia, 16(1): 67-151.

Marinho, M. M. F., F. R. Carvalho, F. Langeani \& F. L. Tatsumi. 2008. A new Hemigrammus Gill from upper Paraná system, southeastern Brazil (Characiformes: Characidae). Zootaxa, 1724: 52-60.

Mirande, J. M. 2009. Weighted parsimony phylogeny of the family Characidae (Teleostei: Characiformes). Cladistics, 25(2009): 1-39.

Reis, R. E., S. O. Kullander \& C. J. Ferraris (Eds.). 2003. Check List of the Freshwater Fishes of South and Central America. Porto Alegre, Edipucrs, 729p.

Taylor, W. R. \& G. C. van Dyke. 1985. Revised procedures for staining and clearing small fishes and other vertebrates for bone and cartilage study. Cybium, 9: 107-119.

Zarske, A. \& J. Géry. 2007. Hemigrammus geisleri sp. n. - ein neuer Glassalmler aus dem zentralen Amazonasgebiet, mit einer erganzenden Beschreibung von Hemigrammus mimus Böhlke, 1955 (Teleostei: Characiformes: Characidae). Vertebrate Zoology, 57(1): 5-14.

Zarske, A., P.-Y. Le Bail \& J. Géry. 2006. New and poorly known characiform fishes from French Guiana. 1. Two new tetras of the genera Hemigrammus and Hyphessobrycon (Teleostei: Characiformes: Characidae). Zoologische Abhandlungen, Staatliche Naturhistorische Sammlungen Dresden, Museum für Tierkunde, 55: 17-30. 